\title{
Los cuatro jinetes de la corona
}

\section{Angelina Muñiz-Huberman*}

Cidade do México, México

amhuber@unam.mx

Se abrió el pergamino de los siete sellos

no ayer sino hoy.

Cuatro jinetes saltaron de las páginas

cuatro caballos

blanco, rojo, negro y amarillo

no ayer sino hoy.

Salpicaron a su paso el aliento de la muerte gotas de rocío, espuma, saliva trasparentes, de cristal.

Diamantes de la corona extraviados signo de todo mal envuelto en dolor el Invisible recoge su manto y los caballos al galope no pueden ser detenidos.

Blanco sin principio ni fin, niega su luz rojo de sangre en éxtasis derramada negro de hambre desmaya los trigales amarillo de muerte acecha en las esquinas.

No ayer sino hoy.

La corona de la creación se desmorona no el Invisible sino los invisibles todopoderosos.

Entran y salen de uno a otro confín espuma entre las manos batida saliva que se esconde humillada sola la esperanza del rocío baila máscara de otros tiempos cubre deseos de no ser reconocidos.

\footnotetext{
* Professora e escritora.
} 
Como si así se ahuyentara

la corona de todos los tiempos

en este nuestro tiempo renacida

al galope de los cuatro caballos

enloquecidos.

No ayer sino hoy.

Recebido em: 10/07/2020.

Aprovado em: 17/07/2020. 